\title{
Love and Fear in the Neighbourhood: \\ Emotions and Ontological Security in Foreign Policy Analysis
}

Viktoria Akchurina and Vincent Della Sala

At a meeting to discuss German-Russian energy relations in Sochi in 2007, Russian President Vladimir Putin allowed his pet dog to enter the room and approach German Chancellor Angela Merkel, widely known to have a very deep fear of dogs. Merkel's fearful expression was captured in widely diffused photos and Putin was heavily criticised in the European press for engaging in the politics of fear. Merkel downplayed the whole event by saying, "I understand why he has to do this-to prove he's a man. He's afraid of his own weakness. Russia has nothing, no successful politics or economy. All they have is this" (Packer 2014). Whether Putin was really trying to frighten Merkel or not is debatable, as is Merkel's speculation of his motives. What is interesting and important for our discussion is that the political commentary used it as further proof that a major international power resorts to the politics of fear, especially in relations with actors who are supposedly primarily interested in fostering closer (economic) relations. Moreover, it fits into narratives that each side has of themselves and of the other, narratives that frame emotions such as love and fear.

The aim of our paper, which explores how Russia and the European Union use emotions to generate "a sense of self", is two-fold. First, it wants to contribute to the growing literature on the role of emotions in international relations by exploring how emotions-in this case love and fear - are fundamental to ontological security. The literature on ontological security has started to look at how the sense of self is an emotional state. We take a slightly different approach and explore the extent to which love and fear are part of the practices and routines that give the EU and Russia ontological security and shape how they relate to each other. Emotions, we will argue, are not just what we feel but also what we do to make sense of the world and to transmit to others how we understand it. We understand who we are by the 
emotions we practice and which shape how we act. Second, we argue that the narratives at the heart of the conceptual and normative maps that guide their actions and behaviour create a sort of (ontological) security dilemma; that is, behaviour aimed primarily at enhancing confidence in the identity and continuity of a political community raises alarms for the ontological security of other actors.In this way, emotions are routines that are both reflexive and relational. Russia and the European Union seemingly derive their ontological security in different ways, with the Russia firmly rooted in narratives of territory and material power while the EU defines itself as a post-territory, post-sovereign polity. However, each also has narratives of love and fear that may lead to ontological insecurity in the other. Our aim is not to deny that material power and interests are not important to either side but that how each side sees itself shapes how it interprets the actions of others and how they act, when and why

We want to contribute to the growing literature on emotions and narratives in international relations as well as that on ontological security. We examine the narratives of the EU and Russia,both towards one another and in relation to what they call their "shared neighbourhood", which includes the disputed territories of Ukraine, Moldova, Georgia, Azerbaijan and parts of Central Asia. While Russia's territorial politics seems to follow the classical realpolitik logic, the reasoning about it goes beyond the notions of sovereignty, if at all. They are about emotional bonds, responsibility and protection that makes them paradoxically similar to the EU's normative reasoning that also goes beyond sovereignty. We address this paradox by combining the methodology of narrative analysis and the genealogy of how love and fear became routines that made the world understandable in the post-Cold War period.

Drawing from relational sociology (Emirbayer 1997), this article examines the process whereby the mutual constitution of ontological security is created by the EU and Russia through different proxies of international relations. It claims that both the EU and Russia use 
narratives of fear and love to project their power in overlapping strategic neighbourhoods. This claim unfolds in three steps. Firstly, we provide a general overview of the discussion of narratives and ontological security, both conceptually and politically, as well as examining where on that map the official debate places Russia and the EU. Secondly, we examine narratives of fear and love by each of the actors through their official narratives. Finally, we show that each side narrates the other in terms of fear and themselves in terms of love. For instance, Russia is increasingly using the narrative of love in its neighbourhood in order to present itself as an inclusive social realm and a benevolent force, which aims at the creation of a "we"-community as opposed to the EU's perceived "stigmatization" approach (Zarakol 2010) but sees European criticism of Russian behaviour - from human rights to claims of Russian disinformation campaigns - as attempts to create fear about its neighbour to the east.

\section{On love, fear and ontological security in politics}

Fear has been a part of our understanding of politics and international relations for a long time. For classic political philosophers central to the development of realism in IR, such as Hobbes and Machiavelli, fear was an instrument that needed to be tempered but could also be used to make friends and punish enemies to achieve strategic aims. On the other hand, Edmund Burke saw emotions such as fear as an obstacle for rational agents, claiming in $A$ Philosophical Enquiry, that, "No passion so effectually robs the mind of all its, powers of acting and reasoning as fear"(Burke 1990,53). We want to examine and challenge both these views of emotions, looking to the ways in which emotions can indeed be the basis for action and meaning in social relations but not necessarily as simply instruments used by rational actors to change the behavior of others.

More recently, interest in emotion in international relations and geopolitics has contributed to our understanding to how social actors behave that goes beyond the mere assumption of rational calculation (Crawford 2014; Hutchison and Bleiker 2014; Pain 2009). 
Most of this attention has been focused on how emotions, especially fear, have been used strategically by actors to exert influence over others. However, trying to instil fear or induce solidarity is similar in some ways to rational calculation: emotions stem from an actor's sense self and how they make sense of the world and their place in it. Actors have practices and routines based on emotions that help construct a continued sense of self - ontological security - around them. Putin letting his dog loose has meaning because it fits into a narrative that Russia wants to construct and others may want to have of Russia. Merkel, for her part, views Russia as an actor that only constructs the world through the lens of fear, not having the resources that Europe uses to seek an order based on fraternity, openness and inclusivity.

Ontological security is a conceptual tool that allows us to begin to trace what gives actors agency. It helps identify the cognitive and normative maps that actors use to decide when to act, how and why. It is based on the premise that before actors act, they need to have the security of who they are as a political community: a polity has practices, routines and narratives that help define who it is and why it remains as a political community (Mitzen 2006a; Steele 2008). Giddens argues that all social actors seek out a sense of being that is constant and which creates the conditions for agency (Giddens 1990, 92). They derive this sense of self through habits, practices and routines, which may also tell us something about how what can seem a random social world becomes legible (Delehanty and Steele 2009) and organised to guard, "against the paralytic, deep fear of chaos" (Mitzen 2006b, 347). States and international actors, then, have "self-identity" needs which can be instrumental in guiding their action (Steele 2008, 148). This is achieved when there is a "consistent feeling of biographical continuity where the individual is able to sustain a narrative about the self and 
answer questions about doing, acting and being" (Kinnvall 2006, 30-1). Narratives, therefore, can tell us something about ontological security, which can be a useful lens to understand why and when actors decide to act.

There are many different ways in which we can assess these needs and use them to help us understand how and why international actors act. Narratives and narration - that is, how actors "emplot" events, places and other actors - can be useful in that they have a number of elements that can establish cognitive and normative maps to make sense of the world (Auerbach 2009). Narrative is above all else a structure or a form in the construction of events, assembling actors, actions and events in a way that makes their unfolding comprehensible and gives them meaning (Ricoeur 2010). Successful narratives can contribute to this sense of understanding the world in which political action takes place as they make the world understandable and legible. As Subotic argues, "States, therefore, construct "autobiographical identity narratives" to make sense of their own behaviour in the international system, to give their actions meaning" (Subotić 2016). These narratives have consequences for the capacity of actors to act and the choices they make (Krebs 2015, 813). For instance, a national autobiography that tells the story of a country like Canada as an evolving laboratory of diversity is more likely to tell the story of immigration as one of solidarity and kindness amongst strangers rather than one of fear and uncertainty.

We want to explore the extent to which two different kinds of international actors - the European Union and Russia - craft autobiographies around the narratives of power of political space and each other, highlighting the extent to which they may guide political action. We do not argue that material power is unimportant but that how it is interpreted can tell us something about how actors make sense of themselves and the world around them. More specifically, we will look to the polyphony of narratives of love and fear; how Russia and the EU use both narratives to give sense to who they are and why they act. 
Russia and Europe (by this we mean the EU and its member states) have a complex history in trying to establish order on the continent. There are a number of different ways that we can begin to understand how Russia and the European Union relate with respect to each other: as rival, partner, friend or enemy (Bechev 2015; Haukkala 2017; Kuzemko 2014; Makarychev 2015). All of these make valid contributions to our understanding of what drives the behaviour of actors in the region. However, it might not tell us as much about how actors define what their interests are, why they are important and why they decide to act in some instances but not others. Relations between the two may be driven by material security needs but they are also shaped by the need to affirm and confirm who they are and why they exist as a political community and as international actors: they seek ontological security. Political communities have a series of practices and routines, including narratives, whose aim is to affirm the reasons for their creation. These do not take place in a vacuum and in the attempt to enhance their ontological security, they may pose a threat to that of others. Narratives and counter-narratives that may be aimed primarily at a domestic audience may lead to increasing mutual ontological insecurity (Lupovici 2012).

\section{Narrating love and fear}

Fear is an emotion that has given birth to the modern Leviathan and political order based on the modern state. Conventional accounts of power and governance in international relations dance around "the power of fear which has been probably a component of most social orders" (Lebow 2008, 4). Fear has been a powerful tool to "obscure reason, intensify emotions and make it easier for demagogic politicians to mobilize the public on behalf of the policies they want to pursue" (Brzezinski 2007). The recent literature on emotions in international relations has tried to argue that they can be collective experiences that can become the basis for behaviour by social groups and actors (Fierke 2013; Mercer 2014; Ross 2014). 
Understanding narratives of fear and love can shed light on the types of social worlds Russia and the EU are trying to create. According to Lebow, "fear-based worlds are highly conflictual, and neither the ends nor the means of conflict are constrained by norms" (Lebow $2008,516)$. This is similar to what Alexander Wendt calls the world of a Hobbesian war in contrast to that of the Kantian world (Moelder 2011; Wendt 1999). The EU has been commonly perceived as a Kantian "normative actor" (Manners 2002). However, the normative turn in International Relations has led to the necessity of creating stigmas and creating oppositional categories, one of which was the perception of Russia as a Hobbesian actor, one who was understood as needing to generate fear (Zarakol 2011). Europe's "other" was not just its past, as Waever contends, but also a resurgent and revisionist Russia that does not play by the same "normative" rules (Neumann 1999). Narrated as a "reactionary actor", Russia had to face the "necessity to play by someone else's rules [...] and subordinating [its] national interests to ideological dogmas" (Astrov and Morozova 2012, 197). It is thus perceived as generating fear, even when faced with an actor such as the EU that has supposedly rejected power politics and its attendant politics of fear.

Emotions, as Jonathan Mercer argues, are also relational in that groups share and validate their feelings, that can then structure how they relate to other groups (Mercer 2014, 516). The practices that lead to individuals consciously being aware that they share feelings with others and thus constitute a group can create ontological security. Sharing grief at the death of a national political or cultural figure, along with the practices that make that sharing of emotions, can provide ontological security for a political community. It is not simply a question of "othering" but of pointing out that there are alternative identities or different groups for whom the sharing of those emotions will not have the same meaning (Rumelili 2004). The construction of love and fear is a way of identifying who we are and who we are 
not. We "love" those with whom we share borders and social practices, our community of fate, and we may fear those who do or do not speak of love like we do. As we will see below.

While fear is given an almost 'by default' place in IR literature on power, love-related narratives or the "indirectness of power" have been slightly neglected (Casier 2018). The IR literature has focussed on fear, as love as has been considered an "anti-political human force" (Arendt 1958). Love is illusive and elusive. It is like power: "difficult to explain, but easier to experience" (Nye 1990,170). However, "love" has a place in power games when it is used for the sake of legitimizing political actions or in search of political recognition. By using this concept we attempt to capture a dimension less visible than that of the Luke's third dimension, that is Foucauldian "internalization" and Casier's "indirectness" of power (Casier 2017).

The love narrative - defined and captured here through narratives on "unity, community, fusion of identities" and similar categories - can be seen as the movement towards a "we", a community, which may signify an inclusive political space, but which may also mean a voluntary loss of autonomy (Nozick1989; Fisher 1990; Solomon 1988). It is about creating a continued sense of self through narratives that are about inclusion, about attachment to others, territory or even ideas. It is one in which conflict and power is silent or even to be contested. It is seemingly reflective in that it is meant to create the "bonds" that hold together a political community. As we will see below in the cases of Russia and the EU, it is also meant project a sense of self towards others.

The love narrative also has a relational counter-narrative of fear, identifying something beyond the borders that leads to the hearth of belonging and attachment. Furthermore, fear as such can be a result of the annihilation of love. As Veronique Pin-Fat (2019) explains in her article, referring to the Shakespeare's King Lear, the lack of proof for the very existence of love does not mean that love does not exist or "we must pass the threshold of knowability in order 
to love one another" (Pin-Fat 2019, page). The knowability of love would have to pass several socialization processes, such as institutionalization (capturing emotion in the social structures), creation of cultural archives (say, connecting the individual emotion to the collective through the emotion of patriotism, ethnocentrism, nationalism and the like). Indeed, King Lear got the proof of Cordelia's love only as she died, but her death also annihilated his own existence. The same can be seen in the relations between EU and Russia when the EU's narrative of Russian foreign policy as proof of its inability to "love" raises questions about the EU's own sense of self in an increasingly uncertain and fearful neighbourhood. Hence, ontological security is not only grounded in the beliefs and values about oneself, but lies also in the capacity to "acknowledge the reality of others", where "acknowledgement is not a form of epistemological recognition but rather a practice - a way of standing to the world and the others" (Pin-Fat 2019, 199). Neither Russia, nor the EU seemed to have a capacity to acknowledge their distinct realities. The EU could not understand why the case of Crimea almost represents the expression of the collective empathy and patriotism, love if you will (even if that is mostly the remnant of Soviet memories), while Russia could not grasp the borderless reality of the European Union.

Narratives of fear and love can form the search for recognition, which Morghenthau calls the "animus dominandi" in politics and Richard Lebow refined as a "self-esteem" or "honour" can distil political actors into the "spirit-, reason-, or appetite-driven" actors (Lebow 2008, 64). Russia justified its annexation of Crimea through a love narrative, appealing to instances such as “common bond, descent, friendship and mutual obligation”. Indeed, Putin's interview with the German periodical, BILD, underlines that "Crimea was about people [rather than] about the borders" (Putin 2016). According to this story, it is the responsibility to protect the Russian people in Crimea and the bond of the "Russkijmir" that had driven 
Russia to comply to the results of the people's referendum in Crimea. Similar rhetoric is used by Russia in the Eurasian neighbourhood.

In sum, the link between narratives of love and fear and the evolving post-Cold War political order can exemplify the processual and relational ontology of foreign policy. They represent an instance of what Giddens (1990) calls the "structuration" and mutual constitution, Foucault's (1975) “subjectification" and Bourdieau-inspired "processes of evolving agency" approaches (Guzzini 2016, 3) as narratives representing an instance of competition and dispositional struggles in the field of power, having the potential to (re)shape political positions and world hierarchies over time (Leander 2008). Narratives about rejecting power politics along with fear and uncertainty by breaking down borders and reversing history, essential to the EU's sense of self, may be seen as threatening to others. At the same time, wanting to extend fraternity to nationals outside national borders or to preserve national traditions from outside values may be seen as a threat to the EU's sense of self. Clearly, there is a material basis to these perceived threats but they are raise "existential" issues that get to core questions about what holds political communities together.

\section{Love and Fear in the EU}

The EU, often presented as a monochromatic technocracy that has eschewed the "irrational" and affective appeals of the modern state (Della Sala 2016). Yet, it too has a narrative of love, one that gives a story of the "we" to keep fear at bay. Its foundational story is about overcoming centuries of hatred and distrust to find the basis for an open, inclusive society that rejects not only that history and geography as the basis for defining political community. For instance, even the Schuman Declaration, announcing of the integration of industrial sectors such as coal and steel has a narrative of belonging and attachment to counter fear and uncertainty. It begins by pointing out that it was fear, rooted in nationalism, which had led to war in Europe. It goes on to weave a narrative of inclusion and solidarity, not 
only between the members of this coal and steel community in Europe but potentially every one else in the international system, especially Africa. This coming together would be, "it may be the leaven from which may grow a wider and deeper community between countries long opposed to one another by sanguinary divisions" (The Schuman Declaration - 9 May 1950). The Declaration is not just about promoting and converging economic interests but also a narrative about the "movement to a we" that is inclusive and does not set out to exclude a priori.

Right from the start, European integration was narrated as a process that wanted to create an international order that was not based on fear and uncertainty. The EU was to be an "exceptional" actor in a new international system. This narrative is rooted in the notion that Europe's distinctive path to peace and stability has made it a different kind of actor on the global stage. It is not about exclusion but about extending this method for peace as a way for states to build an international order based on trust and solidarity. As European Commission President Romano Prodi argued in 2001:

[T] he Union has a role to play in world "governance": In relations between European States, the rule of law has replaced the crude interplay of power. After so many bloody conflicts, the Europeans have declared their "right to peace". That gives us a very special role to play: by making a success of integration we are demonstrating to the world that it is possible to create a method for peace. Within the Union the influence of individual States is not the only criterion, alliances have no role to play. In a word, power politics have lost their influence. This is a considerable achievement which could facilitate the establishment, at international level, of the ground rules that globalisation demands (Prodi 2001).

There seems to be a grand narrative here of a global order that can be forged from the unique European experience. Europe's "power" stems not from its material capacities but 
from it very own experiences (Pace 2007). It is "a poetry of values" that rejects establishing boundaries a priori and aims to instil trust where there was once suspicion and uncertainty.

Every liberal, open society needs the poetry of values to retain a healthy narrative of self. The EU, built on shakier, more artificial foundations, needs it twice as much. If the EU gives up too much of its values-based self, it may easily suffer irreparable damage. No wonder that it is often easier for the EU to stay on the sidelines than to get kneedeep in the geopolitical struggles in its wider neighbourhood (Techau 2013).

It is not hard to find evidence that collective actors within the EU's institutional and political architecture identify with the narrative that the EU has a special role to play in international relations because of who it is and not what. A colourful example comes from a comic book produced by ECHO (the EU's humanitarian and disaster relief agency) called, Hidden Disaster. It tells the story of the response to an earthquake in a fictional country (presumably in the Caucasus or central Asia) riven by an internal conflict between the central government and rebel forces. It focuses on the actions of EU officials, in Brussels but primarily in the field. There is never a hint that the EU might have some sort of strategic interest in the area or itself be responsible for a politics of fear or exclusion; its only concern is with ensuring that aid reaches the needy in the rebel-held areas, which are out of bounds for other relief agencies as the revels do not trust those delivering aid. The very earnest protagonist, the ECHO field officer, sets out to convince the rebels to seek out relief help. She meets with their leader, who looks uncannily similar to Lenin, and convinces him that there are no hidden motives in the relief effort. The "hidden disaster" is not the earthquake but the politics of fear that prevents aid getting through. The EU is present to project that actors may be driven by more than just strategic interests and are not out to exploit fear but to dispel it.

Leaving aside the public information function served by publications such as Hidden Disaster, we find so many of the elements of the EU's narrative of being the promoter of an 
international system based on openness and a wider "we". First, the strength of the EU as an international actor is that it renounces narrow interests associated with national forms of identity and belonging. For instance, the rebel leader refuses to have international aid come through because it would show that his people are not capable of governing themselves, preventing him from accepting that opening up to the international community is a positive sum outcome. His fears are assuaged by the noble intentions and narrative of the EU rescue mission. This narrative of the noble EU in a cruel, uncertain world is evoked time and again as a way of giving meaning to the EU (Manners and Murray 2016). Second, there are repeated references to the moral imperatives of helping those in need in the international community, but that "national" mismanagement and interests (as well as ideology as evidenced by both the reference to nationalism and leftist rebel movements in the book) often get in the way. Third, the EU, which is neither a state nor an international organisation, is the ideal type of actor to step in as the interface between the international community and those in need. Moreover, it is not this institutional ambiguity that gives the EU a special role but that it is the embodiment of values and norms that have guided its evolution.

However, the EU also has narratives of fear and uncertainty that are meant to create a continued sense of self, despite being the arch-type post-modern political structure that eschews the construction of the "other". This is especially the case with respect to Russia. How the EU and Russia interact has much to do with how they view each other as much as it does with shared or conflicting interests (Bechev 2015). As Tom Casier argues, "the EU acts on the basis of what it believes Russia has become. The Union and its member states redefine the identity of Russia, aggrandise differences between perceived 'European' and Russian identities and eventually - in a context of rather acrimonious relations - read bad intentions into Russia's behaviour. Something similar happens the other way around. Russia is primarily led by the images it holds of the EU" (Casier 2016,13). The EU clearly identifies with its 
"foundational" values rooted in liberal democracy and has constructed a narrative about its birth that sees its formation as the conclusion of the crisis caused by nationalism and the opening chapter of a new narrative of political belonging, territory and sovereignty.

This clash of narratives came to a head in the Ukraine. The protestors in Maidan Square were seen as re-telling the story of the EU's creation. As President Commission claimed, "Those young people in the streets of Ukraine, with freezing temperatures, are writing the new narrative for Europe" (Barroso 2014, 325). The EU as the beacon for political communities seeking democracy and prosperity was still seen to be a powerful story not only for the protestors but also for citizens of the EU member states. The peaceful means used by the protestors was contrasted to the strong-armed tactics of the "other", the incumbent Ukrainian government and its Russian ally, by EU officials such as High Representative Catherine Ashton, who descended on to Maidan Square to help write the integration story. In a speech in Poland a few months later, Barroso claimed that,

"Let reason prevail over force" or "Let wisdom prevail over power" could have been indeed the motto of the European Union. A Union built on shared values: peace, democracy, respect of human dignity, and I mean the respect of every man, woman and child, tolerance and justice. It has been since the very beginning the guiding principle of the European integration process. A process built on free consent...Enlargement, or what I prefer to call it: reunification of Europe, has been a key element of the project of a united, free, democratic continent at peace. It also makes Europe more prosperous...That is why our European firm commitment must be now to let reason prevail over the reawakening of the old demons - the demons of populism, protectionism, extreme nationalism, xenophobia. (Barroso 2014, 350).

Barroso is repeating the EU narrative that the expression of material power is not part of the integration biography and that reuniting a community of values was what brought EU officials 
to Maidan Square, not the desire to extend its material power over a political space.

Importantly, it is a story that is told for internal consumption more than to convince others, especially in the face of the recent challenges faced by the EU.

At the same time, it is a narrative of fear. The Russian government's justification of wanting to extend solidarity to Russians in the Crimea or the Ukraine is seen as not just a material threat but also a cognitive and normative one to the EU's sense of self. For instance, Russian legislation in the last decade that limited LGBT was framed in terms of the promotion of "traditional" Russian values, cloaked in references to the a shared past and the bonds of community (Wilkinson 2014). The EU not only contested it but saw its "ontological underpinnings" threatened by this challenge to have its understanding of a "love" narrative, that it sees rooted in universal values, challenged by a different but equally normative narrative that was not about fear and uncertainty (Makarychev 2015, 313; Sakwa 2012). Russian appeal to traditional Russia is useful to construct the narrative practices that allow the EU to give it greater confidence of its continued sense of self. For instance, the Austrian drag queen who won the Eurovision song contest in 2014, Conchita Wurst, was celebrated by European institutions, with promotion of her concert at the European Parliament billing her as, "the European voice". European commentary was quick to point out how the Russian reaction was to condemn her victory as further sign of European decadence (Fumarola 2014).

\section{Love and Fear in Russia}

In his latest Presidential address to the Federal Assembly, Vladimir Putin focused on both love and fear by referring mainly on two issues: the domestic strategy toeradicate poverty and Russian foreign policy. As the mainstream media has already noted, the main part of his speech was devoted to the Russian nuclear potential and its reportedly "invincible weapon" (Putin 2018, Address to the Federal Assembly). This was clearly a different version of sending in the dog to frighten Chancellor Merkel and discussion in Europe was once again 
about how Putin needed to project fear abroad for domestic purposes. But the other narrative of solidarity and unity, crystallised around the fight against poverty, was an equally important part of Putin's message.

An equally important part of Putin's message was devoted to the Russian nuclear potential and its reportedly "invincible weapon" (Putin 2018):

This [weapon] is not a threat to anyone and Russia does not intend to attack anyone [...]. Russian Anti-Missile Defence and Strategy has been developed in response to the United States' unilateral withdrawal from the Anti-Ballistic Missile Treaty of 1972 and practically the U.S. deployment of this system both on the territory of the United States and beyond its borders. [...] Russia sees this Treaty as the cornerstone of the international security system, withdrawal from which can lead to the violation of the international strategic balance. [...] As the U.S. said that it had been creating this system not against Russia, Russia is developing its anti-ballistic missile system not against the U.S. or any other country. [...]"

While Vladimir Putin was appealing to the necessity to defend international norms and power balance, the images of weaponry have played their role in disseminating fear and seeding the sense of (in)security among people. Putin is arguing that Russia had shown in the past that it was not given to spreading fear and had stood by treaties and agreements that were meant to build trust.

While officially not indicating threat, this rhetoric reveals certain nexus between national interest and militarism. In order to legitimize the narrative of militarism, Vladimir Putin explains that poverty in Russia has been partially caused by the international sanctions against Russia. In other words, Russia has been narrated as a victim of international injustice,"a narrative of victimhood feeds policy of permanent self-defence [and the search for] absolute security" (Guzzini 2017, 13), which in its turn leads to the resurrection of the 
security dilemma in foreign policy. Russian official rhetoric on fear tends to start from the United States and scale up to the imaginary "West", which by default embraces the European Union, but not necessarily Europe as an idea and a socio-historical space as such.

Russia has been telling its autobiography as a European one or as part of a "wider Europe" (Sakwa 2012). For example, as Natalia Morozova (2014) rightly notes, there are different definitions of Europe in geography. For example, according to Danilevkii, Europe could have also been defined as a continuation of Asia with Russia occupying a unique position of being a fusion of both, unless the European hegemonic cultural discourse prevails (Morozova 2014). In other words, the way we imagine geography is subjected to a story, a reason, and a power just as much as any other political artefacts. Affinities and relations between or within these entities become defining features of what actors think and know about each other, as well as act accordingly. Hence, today's Russian Eurasianism can be seen as a knowledge-producing mechanism, which evolved out of a story told about Russia by the EU and vice versa.

Thus, the momentum of narrating Russia as an alternative Europe and as an alternative to a Europe, as well as the Russian identity as being closely tied to Eurasianism has been a process, not a doctrine. This process can be arbitrarily divided at least in three stages: classical geopolitical Russia of the 90s, objected and submissive to the alleged "winners of the Cold War" and the "End of History" (Trenin 2018); a Russia in denial, which was mitigating its communist past in favour of its imperial memories in order to overcome the anti-Soviet bias of the rest of the world, which tended "to see Eurasia as a synonym of the common post-Soviet space" (Morozova 2014, 8); and finally a Russia at large, which has come to realize that it cannot continue narrating itself along the lines similar to the Cold War discourse, but rather has chosen to tell a story of an alternative, a truly inclusive and concordant space for Europe, 
Asia and beyond. This process has illustrated a relational nature of a state's ontological security.

While many accounts explain Russian foreign policy as a reaction to its stigmatization by the West (Zarakol 2010), Russia tries to avoid being a reactionary actor by making an idea of Europe and Eurasian space at large part of its ontological security. Hence, juxtaposing Russia to Europe is tearing Russia apart from its own Self. Paradoxically, smaller Eurasian players have been becoming a catalyst for the Russian narrative. For instance, the annexation of Crimea has been cuddled by the narrative of human bond and the responsibility to protect, as we mentioned above. However, while the former Soviet worlds knows Sevastopol' as "historically Russian a city", Western Ukrainians prefer to see themselves as Europeans, relating to Europe through their common memories, while perceiving Russia as an opposite to the EU and to the "civilisation" in general a country. Paradoxically, at the times of the confusion of meanings, the presumably "weak" states like Ukraine (as well as Central Asian or Caucasian states) become the meaning-makers, which is why it is important to look not only at narratives directly concerning Russian politics towards the EU, but also the proxies of that politics.

While the fact of annexation of Crimea and the hybrid war in Ukraine and Syria are seen by the "Western" international community as actions fuelling a new Cold War, Russian President diverts this flow of reasoning by continuously invoking the narratives of love and ethics of responsibility across the "Greater Eurasia" and through indirect platforms, such as for example Putin's opening speech at the BRICS Summit and the meeting of the Council of the Heads of States of the Shanghai Cooperation Organization (SCO) and the Eurasian Union in 2015. Specifically, Putin states that "Eurasian space for Russia is not a chessboard for geopolitical games, but rather a home, where prosperity and peace should rule [...]." While this narrative does not directly contradict the "Western" accusations of Russia as being a 
geopolitical player, it does indirectly lead to something what some scholars call "intimategeopolitics" or the intertwining of global security spaces with local stories (Pain et al. 2014). Russia has been trying to make emerging spaces of trust intersect by organising their meetings at the same time and place, as well as materialising the stories and spaces through concrete international institutions. This process of going from a story to a material structure can be exemplified by the Summits of BRICS, the SCO and the Eurasian Union in 2015, which took place in Ufa on 8-9 July 2015.

In 2017 Vladimir Putin in his address at the opening of the Belt and Road international forum in Beijing underlines the inclusiveness of the newly developed wider Eurasian space by inviting the EU to join in:

I believe that by adding together the potential of all the integration formats like the EAEU, the OBOR, the SCO and the ASEAN, we can build the foundation for a larger Eurasian partnership. [...] We would welcome the involvement of our European colleagues from the EU states in this partnership. This would make it truly concordant, balanced and all encompassing, and will allow us to realise a unique opportunity to create a common cooperation framework from the Atlantic to the Pacific - for the first time in history. ${ }^{1}$

Concordant and intimate for the sake of equal cooperation is the space offered by Russia through various international platforms. In other words, instead of trying to adjust to the rules created by "others", Russia has been trying to offer a normative framework of its own, topping it up with the economic, military, and social sources of power. Specifically, at the Belt and Road forum, Vladimir Putin defends the idea of "economic nationalism", which has been "a development strategy by rising powers to establish symmetry in economic interdependent

\footnotetext{
1 Vladimir Putin, Speech at the "Belt and Road International Forum" 2017: http://en.kremlin.ru/events/president/news/54491
} 
relations, a balance required for mutually beneficial cooperation" (Putin 2017 "Belt and Road International Forum"). The President has not opposed Russia to Europe, but rather compares different visions of Europe. Specifically, Russia has offered the idea of the "Greater Eurasia", which "establishes the symmetry with Europe and balances Europe's economic coercion [...], harmonising interests and shared neighbourhood", which is again not a geopolitical, but rather a "civilisation-wide project looking toward the future" (Putin 2017, "Belt and Road").The narrative of intimacy in the Russian case materialises through emerging international institutions, which have an ambition to create an alternative world order. For example, the BRICS' New Development Bank and the Asian Infrastructure Investment Bank are aspired to be part of such institutions and attract investors into this newly imagined intimate geopolitical space, which will support "quality integration"(Ibid).

Thus, while invoking narratives of fear, Russia also appeals to love and concordance. While expanding, Russia has been offering its services to those who are ready to follow. Yet, the story's survival depends on how it connects to the reasons of those actors, which are located in parallel and often shadow dimensions of power, such as Ukraine, Central Asia, Caucasus, Eastern Europe, and alike. But this is a story of another article.

\section{Conclusion}

The European Union and Russia are two different political systems and types of international actors. However, they both construct narratives that they see not as disseminating fear and uncertainty but meant to instil solidarity, trust and forging bonds of belonging. The narratives of the politics of love are meant primarily for internal consumption, transmitting to Europeans and Russians the reasons why they exist as a political community. The emotions they are not just what they feel but what they practice, what gives them the confidence to act and the reasons why. 
More importantly, what is meant to extend what we call the politics of love by one side generates ontological insecurity in the other. Love and fear are also relational in that what is meant to create a sense of belonging with one set of borders generates a different set of narratives in another. The EU sees its noble narrative as universal and free of strategic interests. Russia sees it not just as an incursion into its sphere of influence when the EU ventures in the Balkans or the Ukraine but as questioning its sense of self as a political community. The EU sees the projection of values, as opposed to strategic interests, as benign opportunity for all those who wish to join in its convivial order. Russia sees those values as threats to how it understands belonging and space. For its part, Russia also cannot see why actions that it deems as extending terms of belonging can threaten anyone else. It asks why the EU should see its occupation of Crimea and eastern Ukraine as an "existential" threat to the rules-based order that supposedly reigns supreme in Europe when it whole-heartedly supported intervention in Kosovo fifteen years earlier.

Russia and the EU have both narratives of love and fear that are essential to their ontological security. Merkel's statement in the opening paragraph captures the view that Russia projects fear because it has "nothing else". But the EU uses that presence of actors who have "nothing else" as a way to highlight how it is different, how its narratives of solidarity are not based on exclusive notions of belong but on a form of love that is open to all, so long as they are ready to renounce the politics of fear. Russia also has its own narratives of solidarity and attachment, important to help hold together a political community trying to restore its bonds after the collapse of communism and the redrawing of its borders. Those narratives of emotions have shaped its policy decisions as well as generated a politics of fear amongst its neighbours. Both the EU and Russia need these practices of the politics of love to give meaning to who they are; but in a tense neighbourhood, they are increasingly leading to fear and uncertainty. 


\section{References}

Arendt, H. (1958). The Human Condition. Chicago: Chicago University Press.

Auerbach, Yehudith. 2009. "The Reconciliation Pyramid-A narrative-based framework for analyzing identity conflicts." Political Psychology 30 (2):291-318.

Barroso, José Manuel. 2014. European Commission 2004 - 2014: A Testimony by the President. Luxembourg: Publications Office of the European Union.

Bechev, Dimitar. 2015. "Understanding the Contest Between the EU and Russia in Their Shared Neighborhood." Problems of Post-Communism 62 (6):340-9.

Burke, Edmund. 1990. A Philosophical Enquiry. Oxford: Oxford University Press.

Casier, Tom. 2016. "Identities and Images of Competition in the Overlapping Neighbourhoods: How EU and Russian Foreign Policies Interact." In Security in Shared Neighbourhoods, edited by Rémi Piet and Licínia Simão, 13-34. Basingstoke: Palgrave Macmillan.

Crawford, Neta. 2014. "Institutionalizing passion in world politics: fear and empathy." International Theory 6 (3):535-57. doi: 10.1017/S1752971914000256.

Delehanty, Will K, and Brent J Steele. 2009. "Engaging the narrative in ontological (in) security theory: Insights from feminist IR." Cambridge Review of International Affairs 22 (3):523-40.

Della Sala, Vincent. 2016. "Europe's odyssey?: Political myth and the European Union." Nations and Nationalism 22 (3):524-41.

Fierke, Karin M. 2013. Political self-sacrifice: Agency, body and emotion in international relations. Cambridge: Cambridge University Press.

Fumarola, Silvia. 2014. "Conchita fa infuriare la Russia. Vicepremier: "Orrore europeo"." In La Repubblica.

Giddens, Anthony. 1990. The Consequences of Modernity. Cambridge: Polity Press. 
Haukkala, Hiski. 2017. "The EU's regional normative hegemony encounters hard realities: The revised European Neighbourhood Policy and the ring of fire." In The Revised European Neighbourhood Policy, edited by Dimitris Bouris and Tobias Schumacher, 77-94. Basingstoke: Palgrave Macmillan.

Hutchison, Emma, and Roland Bleiker. 2014. "Theorizing emotions in world politics." International Theory 6 (3):491-514. doi: 10.1017/S1752971914000232.

Kinnvall, Catarina. 2006. Globalization and Religious Nationalism in India: The Search for Ontological Security. New York: Routledge.

Krebs, Ronald R. 2015. "How Dominant Narratives Rise and Fall: Military Conflict, Politics, and the Cold War Consensus." International Organization 69 (04):809-45.

Kuzemko, Caroline. 2014. "Ideas, power and change: explaining EU-Russia energy relations." Journal of European Public Policy 21 (1):58-75.

Lupovici, Amir. 2012. "Ontological dissonance, clashing identities, and Israel's unilateral steps towards the Palestinians." Review of International Studies 38 (4):809-33.

Makarychev, Andrey. 2015. "A New European Disunity: EU-Russia Ruptures and the Crisis in the Common Neighborhood." Problems of Post-Communism 62 (6):313-5.

Manners, Ian. 2002. "Normative Power Europe: A Contradiction in Terms?" Journal of Common Market Studies 40 (2):235-58.

Manners, Ian, and Philomena Murray. 2016. "The End of a Noble Narrative? European integration narratives after the Nobel Peace Prize." JCMS: Journal of Common Market Studies 54 (1):185-202.

Mercer, Jonathan. 2014. "Feeling like a state: social emotion and identity." International Theory 6 (3):515-35. doi: 10.1017/S1752971914000244.

Mitzen, Jennifer. 2006a. "Anchoring Europe's Civilizing Identity: Habits, capabilities and ontological security." Journal of European Public Policy 13 (2):270-85. 
___. 2006b. "Ontological Security in World Politics: State Identity and the Security

Dilemma." European Journal of International Relations 12 (3):341-70.

Neumann, Iver B. 1999. Uses of the Other:" The East" in European identity formation.

Minneapolis: University of Minnesota Press.

Pace, Michelle. 2007. "The Construction of EU Normative Power." Journal of Common Market Studies 45 (5):1041-64.

Packer, George. 2014. "The Quiet German." In The New Yorker.

Pain, Rachel. 2009. "Globalized fear? Towards an emotional geopolitics." Progress in Human Geography 33 (4):466-86.

Pin-Fat, Veronique. 2019. "What's love got to do with it? Ethics, Emotions, and Encounter in International Relations." Review of International Studies 45 (2): 181-200.

Prodi, Romano. "For a strong Europe, with a grand design and the means of action, Institut d'Etudes Politiques Paris, 29 May."

http://europa.eu/rapid/pressReleasesAction.do?reference=SPEECH/01/244\&format= $\underline{\text { HTML\&aged }=0 \text { \&language }=\text { EN \&guiLanguage }=\text { en }}$.

Ricoeur, Paul. 2010. Time and Narrative. Vol. 3. Chicago: University of Chicago Press.

Ross, Andrew 2014. Mixed Emotions: Beyond Fear and Hatred in International Conflict. Chicago: University of Chicago Press.

Rumelili, Bahar. 2004. "Constructing identity and relating to difference: understanding the EU's mode of differentiation." Review of International Studies 30 (1):27-47.

Sakwa, Richard. 2012. "The problem of 'the international'in Russian identity formation." International Politics 49 (4):449-65.

Steele, Brent J. 2008. Ontological Security in International Relations: Self-identity and the IR state. London: Routledge. 
Subotić, Jelena. 2016. "Narrative, ontological security, and foreign policy change." Foreign Policy Analysis 12 (4):610-27.

Techau, Jan. 2014. "Why the EU Can’t Play Hardball in Foreign Policy." Carnegie Europe, Accessed 15 November 2014. http://carnegieeurope.eu/strategiceurope/?fa=53872. Wilkinson, Cai. 2014. "Putting “Traditional Values” Into Practice: The Rise and Contestation of Anti-Homopropaganda Laws in Russia." Journal of Human Rights 13 (3):363-79. doi: 10.1080/14754835.2014.919218. 